\title{
School Principals' Reflective Leadership Skills through the Lens of Teachers at Higher Secondary School of Thimphu Thromde
}

\author{
Rinzin Namgyal
}

\author{
Ministry of Education, Royal Government of Bhutan, Bhutan. \\ Received: 03 Jan 2022; Received in revised form: 16 Feb 2022; Accepted: 25 Feb 2022 \\ (C2022 The Author(s). Published by TheShillonga. This is an open access article under the CC BY license \\ (https://creativecommons.org/licenses/by/4.0/)
}

\begin{abstract}
This research aims to determine the reflective leadership level of school principals through the perceptions of teachers in higher secondary schools of Thimphu Thromde. The study used a descriptive quantitative and inferential test method using the random sample of 122 volunteer teachers. Data were collected using a 20-structured reflective leadership scale. According to the research findings, it is understood that teachers consider school principals' reflective leadership traits to be at a very good level. This finding would contribute empirical evidence of how teachers view their principals' reflective leadership skills in schools, and it would help principals to further improve their reflective leadership skill.
\end{abstract}

Keywords - reflective leadership, Principal, teachers, self-awareness, careful observation, and flexible response.

\section{INTRODUCTION}

Bhutan's education journey started with monastic education until 1955 when modern education was first introduced during the reign of His Majesty The Third Druk Gyalpo King Jigme Dorji Wangchuck (Schuelka, 2012). The monastic form of education continues even today and now there is an extensive network of schools and institutes spread throughout the country. The education system in Bhutan had a colonial relic from India and developed its first National Education Policy only in 1976 (Chhetri, 2019). It was in the early 1980s that, the Royal Government of Bhutan took tangible steps away from the Indian education system and adopted a localized curriculum with the implementation of a New Approach to Primary Education (NAPE) in 1986 (Dorji, 2017). However, almost all the school heads were appointed from among the Indian teachers who came to teach in Bhutan because unlike Indian teachers, Bhutanese teachers were less qualified to take headship roles (Gyeltshen, 2020). It was in the mid-1980s that Bhutanese teachers were directly appointed as school heads by the Department of Education inclining with its Bhutanizing curriculum. Those heads of school however lacked the formal training which affected their management practices. Starting from 2003, formal training for school leaders commenced with the introduction of the Master of Educational Leadership and management course at Paro College of Education (Dorji, 2005).

The role of school leadership has been extensively studied by many scholars in different countries, and some studies have also looked into the Bhutanese education system. Reflective leadership plays a key role in successfully maintaining the operation in organizations and in achieving their far and near objectives. To enable this success in school organizations, every employee in the school should be committed to the development and effective operation of the school organization. A reflective school leader is a leader with a high level of selfawareness and awareness about the people around, who can analyse how everyone in the organization shall contribute to both organizational culture and effectiveness, find ways how to naturally channel those characteristics of people into the operation of the organization, come up with efficient solutions to emerging problems during the entire process, and transform the organization into a contented and productive environment.

Accordingly, a reflective leader should be a critical, problem-solving person with metacognitive awareness, logical thinking, and the ability to generate creative ideas. How these competencies are perceived and assessed by others is just as important as their possession. Therefore, assessing the level of reflective leadership of the school principal based on the perception of one's staff, especially 
the most important factor in education; Teacher is one of the most authentic aspects of this study. Since teachers are assigned a high level of numerical thinking ability, they can also be expected to have a higher level of thinking ability. Numerical thinking includes other thinking skills such as critical, creative, and logical thinking that play a big role in relative thinking. It was argued that they would play an important role in understanding and disclosing the high thinking skills of school administrators. Similar works on this topic can hardly be found in the literature. It is therefore expected that this study will fill this gap and, in particular, offer the Ministry of Education (MoE) a perspective to improve the reflective skills of school leaders.

\section{PROBLEM STATEMENT}

Several studies have shown that the decline in quality of education is due to the classroom pedagogy, technology, and assessment in schools (MoE, 2014; Namgyel, 2013; Sherab \& Dorji, 2013; Sherab, 2008) which is a critical attribute in achieving quality of education. More recently, research has highlighted the importance of school leadership in improving the outcomes of a school and its students. Therefore, the role of school leadership has been intensely studied by many scholars in different countries, and some studies have also been examined in the Bhutanese education system. As Somech (2005) noted, it is a school principal who can transform a school environment so that its students and teachers can thrive. Hence, leaders need to understand how their followers perceive their reflective leadership skills in school. The research on the relationship between the leadership style of principals (Sigh et al., 2021; Wangmo, 2021), transformational leadership (Drukpa, 2018; Gyeltshen, 2019; Gyeltshen, 2020), and instructive leadership (Tshering \& Sawangmek, 2016; Wangchuk, 2019) on teacher competence (Sigh et al., 2021), motivation (Mittu $\&$ Tenzin, 2021) and emotional intelligence (Sigh et al., 2021; Wangmo, 2021) reflects on the critical transformation of a school environment and attributes on the success of its students and teachers. But teachers' perceptions of the teachers on the reflective leadership skills of their high secondary school principals remained unexplored.

\section{RESEARCH QUESTIONS}

How do higher secondary school teachers perceive their school principals' level of reflective leadership?

\section{PURPOSE OF THE STUDY}

The purpose of this study was to examine the reflective leadership skills of principals by teachers at higher secondary schools in Thimphu Thromde. This study will provide empirical evidence of how these reflective skills are perceived and assessed by others. Therefore, assessment of the level of reflective leadership of the school principal is based on the perception of his/her employees, especially the most important factor in education; the teacher, is one of the most authentic aspects of this study. The results of this study would also help school principals understand their role as transformative leaders to further improve and strengthen teachers' organizational commitment to achieving school goals. It would also be proposed to the MoE to initiate training programs for all school principals in Bhutan to build reflective leadership skills to accelerate teacher engagement in the school.

\section{LITERATURE REVIEW}

Parlakian and Seibel (2001) define reflective leadership as the key to building a relationship-based organization. It is characterized by three important skills: self-awareness, careful observation, and flexible reaction. Reflective leadership is about confidence related to a leader's ability to know themselves, their strengths, and their limits. It implies that a leader is interested and obliged to examine their reactions, thoughts, and feelings about the job. Careful observation means leaders can decipher the meaning of what they see and hear. The concept of reflective practice has a historical basis and a place in the works of Dewey, Piaget, and Lewin (Imel, 1992). These names generally argued in their work that experience is the foundation of learning but also stressed that reflection is a very important concept in learning (Imel, 1992). Later and more contemporary work also emphasized that reflective practices are effective and necessary to effect the intended improvement in educational institutions (Biggs, 2001; Campoy, 2000; Drake \& McBride, 2000; Kahne \& Westheimer, 2000).

Reflection helps the individual to focus totally on their work, improves their understanding of it, and let enable their colleagues to develop professional practices (Lunenburg \& Ornstein, 1996). It sets the scene for the exposure of differences between the theories set forth by individuals and the practices they have implemented based on such theories (Imel, 1992). Reflective practices provide useful solutions for change and foster it as well. Personal reflection includes cognitive, affective, and motivational components. With this personal reflective awareness, the mind observes and discovers to experience itself. The 
possible outcome of the personal reflection is the consistency of thoughts, feelings, motives, and behaviors (Goleman, 1995). Reflective practices help uncover implicit questions. These vague questions usually lead to inner contradictions and restrictions and their disclosure provides the opportunity for widening the perspective and producing different alternatives (Pellicer, 2008). The main aim of reflective practices is to let the individual gain awareness, openness, and a deeper sense of success. This deep satisfaction of success is unbound to place, time, and things. It is far from the person's experience and inhabits the mind (Sullivan \& Wiessner, 2010). Reflection is used in many fields and the analysis of research in the field of education shows many works in pedagogical practices (Husu et al., 2008; Loughran, 2002). Reflection is also considered a tool for leadership in the analysis of compelling professional problems and situations (Boucher, 2007; Daudelin, 1996; Hill, 2005). Tucker and Russell, (2004), suggest that an individual who is incapable of reflection will also be unsuccessful in every action to solve the problem. In the same way, a leader will have difficulty in defining the problem and developing practices that end without reflection (Densten \& Gray, 2001). Reflection is a dynamic process that lets the leaders manage situations and challenges through various precepts and ideas and helps them change their course to a direction they prefer (Daudelin, 1996).

Pellicier (2001) emphasized that without thorough thinking, people are at the risk of being restricted in their actions, and leaders who act without reflection cannot gain the experiences equal to their work time but have a bad work experience all the way through. Leaders, who witness the continuity of their development, actively reflect upon conceptual problems and risks. In this way, leaders continue to grow and they recognize their strengths and weaknesses. In the meantime, leaders who practice reflection develop a leadership model that supports investigation, originality, and reality-based decisions. Successful leaders continuously analyse what they know and what they need to know to identify dangers on hand (Densten \& Gray, 2001).

This is related to being open to continuous learning through the inspection of personal presumptions and current practices. The leader who gains this perspective of learning is open to transformations that will affect his/her life thereafter (Amey, 2004). Transformation is related to change and through reflective practices, the individual welcomes change healthily and enthusiastically and responds accordingly. In sum, reflective practice is a system of change that develops individuals' thought processes (Rogers, 2001) and thusly helps them bring forth different aspects and actions (Osterman, 1990). Leaders at an administrative position who can apply reflective skills during their leadership as a tool become prominent as reflective leaders.

Thus, this research aims to examine the reflective leadership skill of schools principals through the lenses of teachers at Thimphu Thromde.

\section{METHODOLOGY}

\section{Research Design}

This research employed a quantitative design since many researchers supported that quantitative research design is the best approach to social science research because it provides precise measurements and analysis. Creswell and Creswell (2018) emphasized that in quantitative research design, the researcher will count and classify and create statistical models to explain what is being observed.

\section{Populations and samples}

The target population for this study was teachers from four government and private higher secondary schools under Thimphu Thromde. The purposive sampling method was implemented to find out the School Principals' Reflective Leadership Skills through the Lens of Teachers at Higher Secondary School of Thimphu Thromde. According to Creswell and Creswell (2018), these purposive probability sampling methods provide an opportunity for every population to get a chance of being selected representing the whole population. It can also minimize the bias in the results.

\section{Data collections instruments and procedure}

The data was collected using questionnaires with 20closed-ended questions of "reflective leadership scale. The scale rating was developed based on Bhutanese teachers' context to minimize bias. The data were collected from the 122 teachers from four government higher secondary schools. The questionaries' were administrated through Google form after the prior approval from the school administration and the Dzongkhag office.

\section{Validity and Reliability of the research instruments}

According to Livingstone (2012), "validity is a measure of the degree to which a research instrument measures what it is meant to measure". Firstly, the proper selection of data collection tools to minimize bias and survey questionnaires was modified to fit in the Bhutanese context. The validity of the questionnaires was also discussed with the experts.

Reliability is the measure of the degree to which a research instrument produces stable and consistent results. To develop the reliability of questionnaires, a pilot test was carried out with 50 teachers and tested the Cronbach Alpha value and found 0.932. According to Creswell and 
Creswell (2018), research will be reliable if the value ranges from 0.70 to 0.95 .

\section{Ethical Consideration}

A proper channel ethical approval was obtained from Chief Dzongkhag Education Officer (CDEO), Thimphu Thromde. The requirements for the research including the consent forms, cover letters, and questionnaires were administered through the personal email of the participants. The privacy, dignity, well-being, and freedom of the participants were preserved and protected at all times. The research has maintained the privacy and anonymity of respondents at all stages. The response sheets from the participants were kept protected on the laptop and also in a pen drive. The study also acknowledged all the works of other authors used in any part of the research with the use of a standard referencing system.

\section{Data analysis}

Statistical measurements (SPSS) were employed to analyse the quantitative data. The data collected were subjected to descriptive as well as inferential tests. The structured questions were analysed using mean $(\mathrm{M})$ and standard deviation (SD) to understand the levels of reflective leadership skills of principals through the lens of teachers. The difference in viewing the reflective leadership skill of
School principals between the demographic variables such as gender, qualification, and teaching experience of teachers was analysed using the inferential test.

\section{RESULTS}

The reflective leadership skills of the school principals were determined using the three important skills: selfawareness, careful observation, and flexible response.

\section{Self-awareness}

Table 1 shows the participants' responses to the survey questions related to the self-awareness of school principals on a scale of 1 to 5 as indicated earlier. The higher mean scores indicate a greater level of agreement to the survey items and vice versa. Self-awareness refers to a leader's ability to know herself, her strength, her limitation, her thoughts, and her feelings about the work. The strives for continual learning $(\mathrm{M}=1.59)$, seek feedback $(\mathrm{M}=1.95)$, Learning from mistakes $(M=1.81)$, showtime for the organization $(\mathrm{M}=1.51)$, Maintaining an optimistic outlook $(\mathrm{M}=1.81)$, and innovative solutions $(\mathrm{M}=1.77)$ are cited as important skills to determine the self-awareness of schools principals.

Table 1. Self-awareness skill of school principals from the higher school under Thimphu Thromde

\begin{tabular}{|c|c|c|}
\hline Items & M & $\mathrm{SD}$ \\
\hline $\begin{array}{l}\text { I1. Strives for continual learning and applies that knowledge in any activities in } \\
\text { school. }\end{array}$ & 1.59 & .57 \\
\hline $\begin{array}{l}\text { I2. Regularly seeks feedback on his/her performance and takes feedback into } \\
\text { actions for improvement. }\end{array}$ & 1.95 & .99 \\
\hline $\begin{array}{l}\text { I3. Takes ownership for decisions and accepts responsibility when things go wrong. } \\
\text { Learns from mistakes. }\end{array}$ & 1.81 & .89 \\
\hline I4.Showtime for organization, particularly during difficult times. & 1.51 & .56 \\
\hline $\begin{array}{l}\text { I19. Maintains an optimistic outlook and focuses on the positives in difficult } \\
\text { situations. }\end{array}$ & 1.81 & 1.94 \\
\hline $\begin{array}{l}\text { I20. Generates innovative solutions to effectively resolve any issues in the } \\
\text { organization. }\end{array}$ & 1.77 & 1.08 \\
\hline
\end{tabular}

\section{Careful observation}

Table 2 shows the participants' responses to the survey questions related to the careful observation of school principals on a scale of 1 to 5 as indicated earlier. The higher mean scores indicate a greater level of agreement to the survey items and vice versa. Careful observation means that leaders are skilled at knowing about the meaning of their own and others' behavior, tones of voice, body language, reactions, and consequences of any events. Controlling emotions $(\mathrm{M}=1.90)$ anticipates conflict $(\mathrm{M}=1.81)$, treats people fairly and equitably $(\mathrm{M}=1.84)$, good listening skill $(\mathrm{M}=1.77)$, acknowledges other's opinion $(\mathrm{M}=1.86)$, set performance standards $(\mathrm{M}=1.72)$, achievement of organization's standard $(M=1.72)$, engaged organizational activities $(\mathrm{M}=1.61)$, and Consults with other 
colleagues $(M=1.67)$ are cited as important skills to determine the careful observation of schools principals.

Table 2. Careful observation skill of school principals from the higher school under Thimphu Thromde

\begin{tabular}{|c|c|c|}
\hline Items & $\mathrm{M}$ & SD \\
\hline I11. Stays in control of emotions and does not react negatively. & 1.90 & .89 \\
\hline $\begin{array}{l}\text { I12. Anticipates conflict and uses appropriate strategies to resolve conflict in the } \\
\text { organization. }\end{array}$ & 1.81 & .73 \\
\hline $\begin{array}{l}\text { I16. Makes decisions for the organization's good without favouritism or bias } \\
\text { and treats people fairly and equitably. }\end{array}$ & 1.84 & .95 \\
\hline $\begin{array}{l}\text { I17. Focuses on gaining a clear understanding of others' comments by listening, } \\
\text { asking clarifying questions, and reflecting. }\end{array}$ & 1.77 & .75 \\
\hline $\begin{array}{l}\text { I18. Acknowledges others' opinions and offers a convincing rationale and } \\
\text { makes a strong case, without getting personal or aggressive. }\end{array}$ & 1.86 & .79 \\
\hline $\begin{array}{l}\text { I5. Sets performance standards and conducts regular reviews for long-term } \\
\text { benefits. }\end{array}$ & 1.72 & .66 \\
\hline $\begin{array}{l}\text { I6. Recognizes and mitigates threats to the achievement of the organization's } \\
\text { standard. }\end{array}$ & 1.72 & .68 \\
\hline $\begin{array}{l}\text { I7. Always engaged in organizational activities to instill optimism and } \\
\text { enthusiasm in others. }\end{array}$ & 1.61 & .56 \\
\hline $\begin{array}{l}\text { I8. Consult with other colleagues to assess the key issues of the schools to } \\
\text { develop solutions with long-term viability }\end{array}$ & 1.67 & .72 \\
\hline
\end{tabular}

\section{Flexible Responses}

Table 3 shows the participants' responses to the survey questions related to the careful observation of school principals on a scale of 1 to 5 as indicated earlier. The higher mean scores indicate a greater level of agreement to the survey items and vice versa. The flexible responses require that leaders should know their staff-what their styles are, how they work best, what motivates them, their strengths, and areas for development. Nurturing talent $(\mathrm{M}=1.77)$ identifies the strengths/weaknesses of colleagues $(\mathrm{M}=1.95)$, Encourages collaborative work $(\mathrm{M}=1,54)$, works collaboratively $(\mathrm{M}=1.68)$, and Provides opportunities $(\mathrm{M}=1.70)$ are cited as important skills to determine the flexible responses of schools principals.

Table 3. Flexible responses skill of school principals from the higher school under Thimphu Thromde

\begin{tabular}{|l|l|l|}
\hline Item & $\mathrm{M}$ & $\mathrm{SD}$ \\
\hline $\begin{array}{l}\text { I9. Identifies and nurtures talent. Provides talented people with access to targeted } \\
\text { and 'stretch' development opportunities. }\end{array}$ & 1.77 & .79 \\
$\begin{array}{l}\text { I10. Always identifies the strengths/weaknesses of colleagues and provides clear, } \\
\text { constructive, and timely feedback. }\end{array}$ & 1.95 & .88 \\
$\begin{array}{l}\text { I13. Encourages colleagues to work together in the organization. } \\
\begin{array}{l}\text { I14. Works collaboratively and cooperatively and reward those behaviors in } \\
\text { others. }\end{array}\end{array}$ & 1.54 \\
$\begin{array}{l}\text { I15. Provides colleagues with the opportunity to build their capability and nurture } \\
\text { talents. }\end{array}$ & 1.70 & .66 \\
\hline
\end{tabular}

Differences in the levels of reflective leadership skills perceived by teachers based on demographic variables such as gender, qualification, and teaching experience. 
Table 4. ANOVA results based on demographic variable

\begin{tabular}{|l|l|l|l|l|l|l|l|}
\hline Demography & Variable & N & M & df & f & Sig. & $\begin{array}{l}\text { Post } \\
\text { Hoc }\end{array}$ \\
\hline Gender & Male & 48 & 1.53 & 1 & 2.02 & $.15^{*}$ & \\
& Female & 74 & 1.70 & 120 & & & \\
\hline Qualification & Master & 45 & 1.67 & 4 & .80 & $.52^{*}$ & $.68^{*}$ \\
& PgDE & 46 & 1.58 & 117 & & & \\
B.Ed & 26 & 1.69 & & & & \\
\hline Teaching & Degree & 5 & 1.40 & & & & \\
Experience & $<20$ yrs & 23 & 1.47 & 3 & .42 & $.73^{*}$ & $.63 *$ \\
& $15-19$ yrs & 26 & 1.76 & 118 & & & \\
& $10-14$ yrs & 35 & 1.60 & & & & \\
& $5-9$ yrs & 31 & 1.70 & & & & \\
& $>4$ yrs & 7 & 1.50 & & & & \\
\hline
\end{tabular}

A one-way ANOVA was conducted to determine if the teacher demographic variables exhibited a difference in the way teachers perceive their principal reflective leadership skills as shown in Table 4. There were no observable statistically significant differences perceived by teacher's gender, qualification, and experiences using the Anova test. Tukey's post hoc analysis also revealed that teachers perceived no observable statistically significant differences among those variables.

\section{DISCUSSION}

The purpose of this study was to examine the reflective leadership skills of principals by teachers at higher secondary schools in Thimphu Thromde. This study will provide empirical evidence of how these reflective skills are perceived and assessed by others. Therefore, assessment of the level of reflective leadership of the school principal is based on the perception of his/her employees, especially the most important factor in education; the Teacher, is one of the most authentic aspects of this study. The finding of the study indicated a very good level $(\mathrm{M}=2)$ of reflective leadership skills practiced by the four government higher school principals under Thimphu Thromde. Furthermore, the study confirmed that there were no observable statistically significant differences perceived by teachers' gender, qualification, and experiences on reflective leadership skills of the principals.

The current study was carried out in line with the study by Parlakian and Seibel (2001) which define reflective leadership as the key to building a relationship-based organization. The reflection helps the individual to focus totally on their work, improves their understanding of it, and let enable their colleagues to develop professional practices (Lunenburg \& Ornstein, 1996). The study suggested that principals of higher schools under Thimphu Thromde need to move away from a positional approach to a reflective leadership approach.

Based on the findings of this study, the fact that teachers perceive their school principals' reflective leadership skills to be at a very good level is very hope-inspiring. This finding not only shows that reflective leadership is a natural asset of school principals without any specific training on the subject, but also that this skill can be enhanced through training (Sullivan \& Wiessner, 2010). School principals' awareness of their relationship with their followers as reflective leaders can rise (Ollila, 2000) and their awareness of themselves and others can be further developed. In this way, a big contribution can be made to their reflective leadership skills, which -in a waymeans life-long learning as well.

The results of this study provide several practical implications for further improvement of reflective leadership skills in Bhutan, and even more so among school leaders. This study is aligned with some key policy documents such as Bhutan Civil Service Rules and Regulations ([BCSR], 2018) which highlighted that civil servants of Bhutan in leadership positions are equipped with the right competencies to enable them to become an effective leader. In section 26.7.2 the effort will be to ensure that civil servants in leadership positions have a clear idea of what is expected from them and receive the necessary training that covers the development of desirable leadership traits as per the Leadership Capability 
Framework and domain expertise required for the appointed position. The study indicated that, although the reflective leadership skill of school principals was at a very good level, there was room for the principals to further improve their reflective skills.

A strong positive relationship between school leaders and teachers needs to be built with more modern approaches than just taking leadership roles. Therefore, the way school leadership functions in a given situation need to be realized to achieve better employee engagement and organizational productivity. Thus, the Ministry of Education in Bhutan may look forward to providing continuous and sustained PD programs progressively to principals to ensure professional standards of dynamism, calculated risktaking, strategic planning, content knowledge on curriculum, and reflective leadership skills.

\section{CONCLUSION}

The purpose of this study was to examine the reflective leadership skills of principals by teachers at higher secondary schools in Thimphu Thromde. According to the findings teachers perceive the level of reflective leadership of their principals as very good. Their perception of school principals is not affected by the teachers' gender, qualifications, and experiences. The study suggested that principals of higher schools under Thimphu Thromde need to move away from a positional approach to a reflective leadership approach. This study puts forward very important results regarding the reflective leadership levels of school leaders in the Bhutanese educational context.

\section{LIMITATION}

Data was collected using only the quantitative approach of four higher secondary school teachers and their perceptions on principals' reflective leadership skill practices. Therefore, the finding cannot be generalized to all the schools in Bhutan. However, future studies could employ mixed method studies to include interviews and open-ended techniques to gain a better understanding and insights from teachers.

\section{REFERENCES}

[1] Amey, M. (2004). Learning leadership in today's community college. Community College Journal, 74(4), 7-9.

[2] Biggs, J. B. (2001). The reflective institution: Assuring and enhancing the quality of teaching and learning. Higher Education, 41(3), 221-38.

[3] Boucher, C. (2007). Using reflective practice as a management development tool in a victorian health service. Reflective Practice, 8(2), 227-240.
[4] Campoy, R. W. (2000). Teacher development: Fostering reflection in a post-structural era. Contemporary Education, 71(2), 33-41.

[5] Chhetri, K. K. (2019). Preparing Teachers for Inclusive Education in Bhutan. [Doctoral thesis. Brisbane]. Queensland University of Technology. 10.5204/thesis.eprints. 134082 .

[6] Daudelin, M.W. (1996). Learning from experience through reflection. Organizational Dynamics, 24(3), 36-48.

[7] Densten, I.L., \& Gray, J.H. (2001). Leadership development and reflection: What is the connection? The International Journal of Educational Management, 15(3), 119-125.

[8] Dorji, J. (2005). Quality of education in Bhutan: The story of growth and change in the Bhutanese education system. Thimphu: KMT publisher.

[9] Dorji, R. (2017). An Investigation of Attitudes and Experiences of Implementing Inclusive Education in Bhutan: Perspectives of Teachers, Principals, and Past Students. [PhD. Thesis]. University of New England, School of Education.

[10] Drake, F. D., \& McBride, L. W. (2000). The summative teaching portfolio and the reflective practitioner of history. The History Teacher, 34(1), 41-60.

[11] Goleman, D. (1995). Emotional intelligence: Why it can matter more than $I Q$. New York: Bantam Books.

[12] Gyeltshen, L. (2019). Principals' Transformational Leadership Style and Organizational Commitment of the Teachers' in Middle Secondary Schools of Bhutan: Quantitative Study. Educational Management and Innovation Journal, 2(2), 71-83.

[13] Gyeltshen, L. (2020). A Study Examining the Influence of Principals' Situational Leadership Practices on Teachers' Organizational Commitment in Bhutan. Journal of Educational and Human Resource Development 8,127-138.

[14] Hill, R. (2005). Reflection as a professional development strategy during organizational change. Reflective Practice, 6(2), 213-220.

[15] Husu, J., Toom, A. \& Patrikainen, S. (2008). Guided reflection as a means to demonstrate and develop student teachers' reflective competencies. Reflective Practice, 9(1), 37-51.

[16] Imel, S. (1992). Reflective practice in adult education. ERIC Digest No. 122 (Columbus, Ohio, ERIC Clearinghouse on Adult Career and Vocational Education.

[17] Kahne, J. \& Westheimer, J. (2000). A pedagogy of collective action and reflection: Preparing teachers for collective school leadership. Journal of Teacher Education, 51(5), 372-83.

[18] Loughran, J.J. (2002). Effective reflective practice: In search of meaning in learning about teaching. Journal of Teacher Education, 53(1), 33-43.

[19] Lunenburg, F. C. \& Ornstein, A. C. (1996). Educational administration concepts and practices. Belmont, CA: Wadsworth Publishing Company.

[20] Ministry of Education. (2014). Bhutan education blueprint 2014-2013. Ministry of Education, Royal Government of Bhutan Thimphu. 
[21] Mittu, H. \& Tenzin,S. (2018). Impact of Leadership Styles of Secondary School Principals on Work Motivation of Teachers in Bhutan. Indian Journal of Public Health Research \& Development, 9(12), 1719-1724.

[22] Namgyel, T. (2013). Teacher-centred instructional delivery affecting student's learning. Journal of the International Society for Teacher Education, 17(2), 60-69.

[23] Ollila, S. (2000). Creativity and innovativeness through reflective project leadership. Creativity and Innovation Management, 9(3), 195-200.

[24] Osterman, K.F. (1990). Reflective practice: A new agenda for education. Education and Urban Society, 22, 133-152.

[25] Parlakian, R. \& Seibel, N. (2001). Being in charge: Reflective leadership in infant-family programs. Washington, DC: Zero to Three. What is Reflective Leadership? • ZERO TO THREE

[26] Pellicer, L.O. (2008). Caring enough to lead: How reflective practice leads to moral leadership (3rd ed.). Thousand Oaks, California: Corwin Press.

[27] Rogers, R.R. (2001). Reflection in higher education: A concept analysis. Innovative Higher Education, 26(1), 3757.

[28] Schuelka, M. J. (2012). "Inclusive Education in Bhutan: A Small State with Alternative Priorities." Current Issues in Comparative Education 15 (1), 145-156. (14) (PDF) Inclusive Education in Bhutan: A Small State with Alternative Priorities (researchgate.net)

[29] Sherab, K. (2008, December 7-10). Bhutanese teachers' pedagogical orientation in the primary classes: A factor on quality education [Paper Presentation]. Proceeding of National Seminar on Quality of Education in Bhutan, Rinpung, Paro, Bhutan.

[30] Sherab, K., \& Dorji, P. (2013). Bhutanese teachers' pedagogical orientation in the primary classes: A factor on quality education. Journal of the International Society for Teacher Education, 18-28.

[31] Singh,H.E., Dorji,N., Zangmo,L., Rigyel, Wangchuk,N., Tamang,L.D. \& Zangmo,N.(2021). A Study on the Relationship between Emotional Intelligence, Leadership Styles and Perceived Leadership Effectiveness in Bhutan. SAGE Journal. https://doi.org/10.1177/0972150920978121

[32] Sullivan, L. G. \& Wiessner, C. A. (2010). Learning to Be Reflective Leaders: A Case Study from the NCCHC Hispanic Leadership Fellows Program. New Directions for Community Colleges, No: 149, Spring, 41-50. https://doi/org.10.1002/cc.394

[33] Thinley, P. (2012). My tryst with education: A personal story. In Ministry of Education. The Centenarian: 100 Years of Educating the Nation. Ministry of Education: Thimphu.

[34] Tucker, B. A., \& Russell, R. F. (2004). The influence of the transformational leader. Journal of Leadership \&Organizational Studies, 10(4), 103-111. 